\title{
Modeling and Forecasting of Arecanut Production in India-Vision 2020
}

\author{
Lakshmi Narsimhaiah*, P.K. Sahu, Sh Herojit Singh, Kanchan Sinha, \\ SoumikDey and Pramit Pandit
}

Department of Agricultural Statistics, Bidhan Chandra Krishi Vishwavidalaya, Mohanpur, Nadia, West Bengal, Pin code: 741252, India

*Corresponding author

\section{A B S T R A C T}

Keywords

Arecanut, Modeling, forecasting, ARIMA, ARIMAx, Combined forecast

Article Info

Accepted:

07 October 2019

Available Online:

10 November 2019
Arecanut is an important plantation crop which India holds number one position in area and production. Arecanut has the never ending list of uses i.e. for chewing purpose, as medicine, as vegetable, as stimulant, fuel wood, lubricant, tannin, wrapping, clothing etc.,(Aman, 1969). Arecanut is facing numerous hurdles adding pressure to the mere survival of the sector not only in domestic but also in international sector. Forecasting methods can help estimate many such future aspects of any business operation and so also in agriculture. ARIMA, ARIMAx and Combined forecast techniques used to model and forecast the area, production and productivity of arecanut until 2020 using time series data for a period of 1965 to 2015. Area of India under arecanut for the year 2020 is forecasted to be 447.581 thousand hectares by the best fitted ARIMA $(1,1,1)$. The estimate of production for arecanut by 2020 found to be $723.834,975.452$ and 849.643 metric tonnes by the best fitted ARIMA $(0,1,2)$, ARIMAx $(1,1,0)$ and combined forecast methods respectively. Similarly productivity by the end of 2020 found to be 1595.966 , 1576.010 and $1585.988 \mathrm{~kg}$ per hectare using the best fitted ARIMA $(0,1,1)$, ARIMAx $(0,1,1)$ and combined forecast respectively.

\section{Introduction}

Arecanut (Areca catechu) is a plantation crop. India holds number one position both in areca nut area and production. Arecanut also popular by name supari or betelnut, is used for chewing purpose. It is one of important commercial crop in South East Asia. Arecanut has the never ending list of uses i.e. for chewing purpose, as medicine, as vegetable, as stimulant, fuel wood, lubricant, tannin, wrapping, clothing etc., Medicinal properties of areca nut which are helpful to cure ailments such as dysentery, diarrhea, heart burn, urinary stones, etc., (Aman, 1969).

Indian plantation sector is facing numerous hurdles like vagaries of weather coupled with 
climatic change, lack of investment, quality cultivars, mostly confined to small holdings, decrease in planting areas due to various reasons like rapid urbanization, labour migration, increased wages, non availability of quality inputs, risks confronted at the marketing sector like stiff competition from global players, trade agreements, tariff structure, government intervention, price transmission from the global markets, fluctuating currency, etc. add pressure to the mere survival of this sector not only in domestic sector but also in international sector.

Planning for the future is a critical aspect of managing any organization, and agricultural enterprises are no exception. Forecasting methods can help estimate many such future aspects of any business operation and so also in agriculture. With the above backdrop there is great need for developing suitable and reliable models using information from different sources like agricultural inputs, meteorological information for providing the reliable and timely forecast of crop production which in turn helps for suitable policy making. The present work is an attempt carried out to study the area, production and productivity which in turn have a motto to foresee what could be the future behavior of arecanut in India.

\section{Materials and Methods}

Depending upon the production performance of the major growing states for arecanut and scrutinizing the data for each state, it was noticed that continuous and quality data were available for Karnataka, Kerala and Assam (produces more than $87 \%$ together) of total Indian arecanut production respective. State wise time series data on area, production and productivity of arecanut and also state-wise NPK fertilizer consumption data for the period of 1965-2015 was collected from Ministry of
Agriculture and Farmers Welfare, Govt. of India and various issues of fertilizer statistics respectively. First data is scrutinized for the presence of any outliers using Grubbs' test. On rejection of outlier or replacement of extreme values if any by median, the data are subjected to test of randomness using turning point test. The most widely used descriptive measure of central tendency and dispersion like minimum, maximum, arithmetic mean, standard deviation, skewness, kurtosis along with simple and compound growth rates are used to explain each series. Each time series is later subjected by two important stationarity testADF (Augmented Dickey Fuller) and KPSS (Kwiatkowski-Phillips-Schmidt-Shin) test. When the data are non stationary, to be brought into stationary by the methods like differencing.

\section{Box-Jenkins [Auto Regressive Integrated Moving Average (ARIMA)] model}

Box-Jenkins time series models written as ARIMA (p,d,q) was first popularized by Box, G.E.P and Jenkins, G.M (1976). This model take care of three types of processes, viz., auto regressive of order $\mathrm{p}$; differencing to make a series stationary of degree $d$ and moving average of order $\mathrm{q}$ as this method applies only to a stationary time series data.

\section{Autoregressive model}

The notation AR (p) refers to the autoregressive model of order $p$. The $\operatorname{AR}(p)$ model is written

$$
X_{t}=c+\sum_{i=1}^{P} \rho_{i} X_{t}+\varepsilon_{t}
$$

where $\rho_{1}, \rho_{2} \ldots . \rho_{p}$ are the parameters of the model, $c$ is a constant and $\varepsilon_{t}$ is white noise. Sometimes the constant term is avoided. 


\section{Moving average model}

The notation MA $(q)$ refers to the moving average series of order $q$ :

$$
X_{t}=\mu+\varepsilon_{t}+\sum_{i=1}^{q} \theta_{i} \varepsilon_{t-i}
$$

Where the $\theta_{1}, \ldots, \theta_{q}$ are the parameters of the model, $\mu$ is the expectation of $X_{t}$ (often assumed to equal 0 ), and the $\varepsilon_{t}, \varepsilon_{t-1}$ are error term.

ARIMAx technique for forecasting of arecanut production and yield

As present performance in production of any crop not only depends on its past performances but also on other supporting input factors, these were also included in the model; as such ARIMAx models were also conceived. ARIMAx model is a generalization of ARIMA model and is capable of incorporating external input variable(s) (X's). ARIMAx is carried for the production and productivity data of the crops considered. Here in the current study annual total nitrogen, total phosphorus and total potassium consumption by states and India as a whole was considered as the external input. Initially, considered input variable(s) (X's) are modeled individually to get the estimated values for the observed data points and forecasted based on the best fitted ARIMA models in respective series. In the second step, these forecasted values are used as auxiliary/independent variable in the ARIMAx models of the production and productivity series. All developed ARIMAx models are compared for error diagnostic criteria i.e. RMSE, MAE, MAPE and value of $R^{2}$. The method which provides lower value of error diagnostic criteria and maximum value of $R^{2}$ is selected as best fitted model for arecanut production and productivity forecasting.

\section{Composite forecast}

To improve forecasting accuracy, combine forecasts derived from methods that differ substantially and draw from different sources of information. Use formal procedures to combine forecasts: An equal-weights rule offers a reasonable starting point, and a trimmed mean is desirable if you combine forecasts resulting from five or more methods. Combining forecasts is especially useful when you are uncertain about the situation, uncertain about which method is most accurate, and when you want to avoid large errors. Compared with errors of the typical individual forecast, combining reduces errors. Combining should be done mechanically and the procedure should be fully described. Equal weighting is appealing because it is simple and easy to describe and the present investigation used it.

ARIMA models, ARIMAx models and combine forecast are selected as best fit models/ or evaluated based on the criteria of $\mathrm{R}^{2}$, RMSE, MAE and MAPE.

\section{Results and Discussion}

\section{Per se performance of arecanut production in India}

Table 1 provides the per se performance of arecanut in India during 1965-2015. From the table one can find that, during the period under study country's average area under arecanut is 256.45 thousand hectares; the maximum area covered was 463.89 thousand hectares, while the minimum area covered was noted to be 131 thousand hectares. Increase in area under arecanut is being reflected in terms of simple growth rate $4.756 \%$ accompanied with a compound growth rate of 2.423 percent per annum. Platykurtic and positive nature of skewness clearly indicates that area under arecanut showed steady changes at early stage and remained almost same during later part of 
study. Among the major nut growing states in India, the maximum growth in area was observed in Karnataka with a SGR of $9.211 \%$ and CGR of $3.435 \%$, followed by Assam SGR-4.154\% and CGR- $2.237 \%$ and Kerala SGR-1.250\% and CGR- $0.968 \%$. In support of the above, average area under arecanut in Karnataka is more compared to all other states, followed by Kerala and Assam. The positive value skewness and negative kurtosis for all states reveals steady changes in area under arecanut has taken place during initial period under study and remained almost same during later part of the study. While in case of Kerala negative value of skewness and platykurtic nature reveals that there has been marginal shift in recent years of the study.

From the table one can find that, during the period under study average production of Indian arecanut was 295.797 thousand tons, with maximum production recorded 746.110 thousand tons, while the minimum production was 113.00 thousand tons. Increase in production of nuts in India is being reflected through simple as well as compound growth rates of $4.73 \%$ and $2.415 \%$ respectively during the period under study. Leptokurtic and positive skewness clearly indicate that production of arecanut showed maximum shift or improvement at early stages.

Among the states considered maximum compound growth rate found in Karnataka with 4.617 (accompanied with SGR-18.182\%) per cent followed by Kerala and Assam with 2.415 and 2.190 per cent respectively. Karnataka even with highest average production i.e., 136.916 thousand tons followed by Kerala 75.163 thousand tons and Assam 51.831 thousand tons.

Arecanut yield of India is varied from 831.461 $\mathrm{Kg} / \mathrm{ha}$ to $1658.470 \mathrm{Kg}$./ha with an annual simple and compound growth rate of 1.435 percent and 1.075 percent respectively. On average arecanut yield remained 1099.678 $\mathrm{Kg} / \mathrm{ha}$ during the study period. In similarity with area and production Karnataka has recorded the highest average highest yield (1417.49 Kg/ha) followed by Assam (949.817 $\mathrm{Kg} / \mathrm{ha}$ ) while Kerala with lowest yield (943.046 Kg/ha). Kerala has the highest CGR and SGR have both highest whereas negative growth is seen in case of Assam. Among the states considered Assam and Karnataka are positively skewed whereas Kerala shows negative skewness. Karnataka shows only leptokurtic behavior which tells the story of presence of higher proportion of places with maximum yield.

\section{Test of outliers and randomness for area, production and yield of arecanut}

In table 2 the results of both the test of randomness and that of outlier are presented for arecanut. No outlier was detected in all data series of arecanut. From the test of randomness one can see that except the yield of arecanut in India area, production and yield of arecanut in Assam, Kerala, Karnataka and India follow some trends.

\section{Modeling and forecasting of arecanut area}

First order differencing was necessary for the series to make it stationary except for area of arecanut in Kerala which required second order differencing. Once the data series are made stationary, various ARIMA models are tried for each series and only best models among the competitive model for each series is selected based on minimum value of RMSE, MAPE, MAE and maximum value of $R^{2}$. Developed models are also put under diagnostic checking through Ljung-Box test of residuals.

From the Table 3, for area under arecanut in Assam, Karnataka, Kerala and India, the best fitted ARIMA models are respectively 
ARIMA $(1,1,0)$, ARIMA $(3,1,0)$, ARIMA $(0,2,1)$ and ARIMA $(1,1,1)$. The results of Ljung-Box test of residuals also reject the presence of significant auto correlation in the residuals for the best fitted model in ARIMA. These models are used for forecasting arecanut area up to 2020 .

The selected models are also validated for accuracy using last three years and observed that the actual and predicted values are in range and same can be observed from Table 4 for the states of Assam, Karnataka, Kerala and India as a whole respectively.

From the forecasted values obtained, it can be noted that area of arecanut in Assam, Karnataka, Kerala and India would be 80.512 , 219.156, 101.351 and 447.581 thousand hectares respectively in 2020 . The forecasted figures compared with the year 2015 indicate that area under arecanut in case of Assam and Kerala would increase in future, whereas area in Karnataka and India as a whole would decrease in future. Thus proper measures should be taken to arrest the decrease in area under arecanut in future.

\section{ARIMA, ARIMAx and Combined model for production of arecanut in India}

When the production of arecanut is considered, from the Table 5 , it can be observed that combined forecasting performed better compared with ARIMA in all cases considering the criteria of $\mathrm{R}^{2}$, RMSE, MAE and MAPE. In case of Assam ARIMAx performed better.

Combined forecasting performed better in case of Kerala and India as compared with ARIMAx. In case of Karnataka both combined forecast and ARIMAx is found completing as $\mathrm{R}^{2}$ is high in ARIMAx and in all the other criteria combined forecast found with improved performance. The combined forecast values of the same can be found in Table 6.

\section{ARIMA, ARIMAx and Combined model} for yield of arecanut in India

When the yield of arecanut is considered, from the Table 7, it can be observed that combined forecasting performed better compared with ARIMA in all cases considering the criteria of $\mathrm{R}^{2}$, RMSE, MAE and MAPE except India where ARIMA performed better compared with combined forecast. Combined forecasting performed better in case of Assam and Kerala as compared with ARIMAx. In case of Karnataka and India both combined forecast and ARIMAx is found completing with each other as per the criteria considered. The combined forecast values of the same can be found in Table 8 .

From the study of past production behavior of areca nut, it is found that for India, increase in area, production and productivity are being reflected in terms of simple growth rates and compound growth rates. Platykurtic and positive nature of skewness clearly indicates that area under areca nut showed steady changes at early stage and remained almost same during later part of study. Among the major nut growing states in India, the maximum growth in area was observed in Karnataka followed by Assam and Kerala. In support of the above, average area under areca nut in Karnataka is more compared to all other states, followed by Kerala and Assam.

The positive value of skewness and negative kurtosis for all the states reveal steady changes in area under areca nut has taken place during initial period under study and remained almost same during later part of the study. While in case of Kerala negative value of skewness and platykurtic nature reveals that there has been marginal shift in area in recent years of the study. 
Table.1 Per se performance of arecanut production in major states of India during 1965-2015

\begin{tabular}{|c|c|c|c|c|}
\hline Particulars & Assam & Karnataka & Kerala & India \\
\hline & \multicolumn{4}{|c|}{ Area ('000 hectare) } \\
\hline Minimum & 22.000 & 35.000 & 57.000 & 131.000 \\
\hline Maximum & 79.000 & 236.800 & 108.600 & 463.890 \\
\hline Average & 56.134 & 94.782 & 78.498 & 256.448 \\
\hline Standard Deviation & 19.275 & 61.279 & 15.803 & 101.769 \\
\hline $\mathbf{C V}$ & 34.337 & 64.653 & 20.132 & 39.684 \\
\hline Skewness & -0.600 & 1.012 & 0.205 & 0.779 \\
\hline Kurtosis & -1.208 & -0.372 & -1.435 & -0.831 \\
\hline SGR \% & 4.154 & 9.211 & 1.250 & 4.756 \\
\hline \multirow[t]{2}{*}{ CGR \% } & 2.237 & 3.435 & 0.968 & 2.423 \\
\hline & \multicolumn{4}{|c|}{ Production ('000 ton) } \\
\hline Minimum & 23.000 & 44.000 & 37.000 & 113.000 \\
\hline Maximum & 78.200 & 460.000 & 128.000 & 746.660 \\
\hline Average & 51.831 & 136.913 & 75.163 & 295.797 \\
\hline Standard Deviation & 15.927 & 103.325 & 27.678 & 163.565 \\
\hline $\mathbf{C V}$ & 30.729 & 75.467 & 36.824 & 55.296 \\
\hline Skewness & -0.469 & 1.789 & 0.433 & 1.194 \\
\hline Kurtosis & -0.834 & 2.719 & -1.333 & 0.606 \\
\hline SGR \% & 4.010 & 18.182 & 4.730 & 9.725 \\
\hline \multirow[t]{2}{*}{ CGR \% } & 2.190 & 4.617 & 2.415 & 3.525 \\
\hline & \multicolumn{4}{|c|}{ Yield (kg/ha) } \\
\hline Minimum & 724.758 & 970.910 & 609.195 & 831.461 \\
\hline Maximum & 1307.692 & 2098.803 & 1302.410 & 1658.470 \\
\hline Average & 949.817 & 1417.949 & 943.046 & 1099.678 \\
\hline Standard Deviation & 135.840 & 192.139 & 227.035 & 179.988 \\
\hline CV & 14.302 & 13.550 & 24.075 & 16.367 \\
\hline Skewness & 0.233 & 1.252 & -0.253 & 0.702 \\
\hline Kurtosis & -0.134 & 4.899 & -1.327 & 0.825 \\
\hline SGR \% & -0.046 & 1.550 & 2.109 & 1.431 \\
\hline CGR \% & -0.046 & 1.143 & 1.434 & 1.075 \\
\hline
\end{tabular}


Table.2 Test of outliers and randomness for area, production and yield of arecanut

\begin{tabular}{|c|c|c|c|c|c|c|}
\hline \multirow{2}{*}{ Test of randomness } & \multicolumn{3}{|c|}{ Assam } & \multicolumn{3}{|c|}{ Karnataka } \\
\hline No. of Observation & Area & Production & Yield & Area & Production & Yield \\
\hline No. of Turning Point (p) & 51 & 51 & 51 & 51 & 51 & 51 \\
\hline $\mathbf{E}(\mathbf{P})$ & 7 & 21 & 25 & 10 & 15 & 23 \\
\hline $\mathbf{V}(\mathbf{P})$ & 32.667 & 32.667 & 32.667 & 32.667 & 32.667 & 32.667 \\
\hline $\mathbf{t}_{\text {cal }}$ & 8.744 & 8.744 & 8.744 & 8.744 & 8.744 & 8.744 \\
\hline Inference & 8.680 & 3.945 & 2.593 & 7.665 & 5.974 & 3.269 \\
\hline Outliers Test & Trend & Trend & Trend & Trend & Trend & Trend \\
\hline & No & No & No & No & No & No \\
\hline Test of randomness & & & & & & \\
\hline & & Kerala & & & India & \\
\hline No. of Observation & Area & Production & Yield & Area & Production & Yield \\
\hline No. of Turning Point (p) & 12 & 51 & 51 & 51 & 51 & 51 \\
\hline E (P) & 32.667 & 17 & 25 & 11 & 21 & 27 \\
\hline V(P) & 8.744 & 8.744 & 32.667 & 32.667 & 32.667 & 32.667 \\
\hline $\mathbf{t}_{\text {cal }}$ & 6.989 & 5.298 & 2.593 & 7.327 & 3.744 & 8.744 \\
\hline Inference & Trend & Trend & Trend & Trend & Trend & Random \\
\hline Outliers Test & No & No & No & No & No & No \\
\hline
\end{tabular}

Table.3 ARIMA models for area under arecanut in India

\begin{tabular}{|c|c|c|c|c|c|c|c|}
\hline \multirow{2}{*}{ State } & ARIMA Models & \multicolumn{4}{|c|}{ Model selection criteria } & \multicolumn{2}{|c|}{$\begin{array}{c}\text { Ljung-Box test } \\
\text { for residuals }\end{array}$} \\
\cline { 5 - 9 } & & $\mathbf{R}^{2}$ & RMSE & MAPE & MAE & $\chi^{2}$ & P Value \\
\hline Assam & $(1,1,0)$ & 0.985 & 2.230 & 3.576 & 1.605 & 17.969 & 0.391 \\
\hline Karnataka & $(3,1,0)$ & 0.974 & 8.946 & 3.915 & 4.362 & 12.328 & 0.654 \\
\hline Kerala & $(0,2,1)$ & 0.894 & 5.093 & 4.478 & 3.537 & 8.208 & 0.962 \\
\hline India & $(1,1,1)$ & 0.973 & 15.037 & 3.520 & 9.351 & 20.520 & 0.198 \\
\hline
\end{tabular}


Table.4 Observed and forecasted area (in ' 000 hectare) under arecanut in India

\begin{tabular}{|c|c|c|c|c|c|c|c|c|c|c|c|c|}
\hline State & ARIMA & \multicolumn{3}{|c|}{ Observed } & \multicolumn{3}{c|}{ Predicted } & \multicolumn{4}{c|}{ Forecasted } \\
\cline { 3 - 16 } & Models & $\mathbf{2 0 1 3}$ & $\mathbf{2 0 1 4}$ & $\mathbf{2 0 1 5}$ & $\mathbf{2 0 1 3}$ & $\mathbf{2 0 1 4}$ & $\mathbf{2 0 1 5}$ & $\mathbf{2 0 1 6}$ & $\mathbf{2 0 1 7}$ & $\mathbf{2 0 1 8}$ & $\mathbf{2 0 1 9}$ & $\mathbf{2 0 2 0}$ \\
\hline Assam & $(1,1,0)$ & 76.570 & 76.570 & 79.000 & 75.800 & 77.152 & 76.570 & 79.937 & 80.298 & 80.437 & 80.491 & 80.512 \\
\hline Karnataka & $(3,1,0)$ & 219.690 & 218.010 & 220.000 & 244.587 & 222.860 & 215.260 & 218.625 & 219.421 & 219.043 & 219.206 & 219.156 \\
\hline Kerala & $(0,2,1)$ & 96.650 & 96.690 & 99.000 & 96.361 & 96.481 & 96.572 & 99.470 & 99.940 & 100.410 & 100.880 & 101.351 \\
\hline India & $(1,1,1)$ & 451.900 & 450.210 & 455.000 & 456.755 & 442.324 & 458.746 & 447.091 & 454.738 & 447.344 & 454.493 & 447.581 \\
\hline
\end{tabular}

Table.5 ARIMA, ARIMAx and Combined model for production of arecanut in India

\begin{tabular}{|c|c|c|c|c|c|c|c|}
\hline \multirow[t]{2}{*}{ State } & \multirow[t]{2}{*}{ Models } & \multicolumn{4}{|c|}{ Model selection criteria } & \multicolumn{2}{|c|}{$\begin{array}{l}\text { Ljung-Box test for } \\
\text { residuals }\end{array}$} \\
\hline & & $\mathbf{R}^{2}$ & RMSE & MAPE & MAE & $\chi^{2}$ & P Value \\
\hline \multicolumn{8}{|c|}{ ARIMA Models } \\
\hline Assam & $(4,2,0)$ & 0.782 & 6.961 & 8.517 & 4.598 & 20.416 & 0.118 \\
\hline Karnataka & $(1,1,1)$ & 0.898 & 24.503 & 5.105 & 8.350 & 15.195 & 0.510 \\
\hline Kerala & $(1,1,1)$ & 0.940 & 6.290 & 5.662 & 4.118 & 12.951 & 0.676 \\
\hline India & $(0,1,2)$ & 0.941 & 32.912 & 5.601 & 18.005 & 9.684 & 0.883 \\
\hline \multicolumn{8}{|c|}{ ARIMAx Models } \\
\hline Assam & $(0,1,1)$ & 0.858 & 6.007 & 7.148 & 3.736 & 19.675 & 0.291 \\
\hline Karnataka & $(2,2,0)$ & 0.948 & 25.023 & 9.517 & 13.893 & 9.970 & 0.868 \\
\hline Kerala & $(0,1,1)$ & 0.957 & 5.921 & 5.771 & 4.223 & 17.018 & 0.453 \\
\hline India & $(1,1,0)$ & 0.958 & 34.704 & 5.558 & 20.582 & 21.403 & 0.209 \\
\hline \multicolumn{8}{|c|}{ ARIMA+ARIMAx } \\
\hline Assam & - & 0.830 & 6.040 & 7.573 & 4.035 & - & - \\
\hline Karnataka & - & 0.930 & 20.249 & 6.986 & 9.805 & - & - \\
\hline Kerala & - & 0.965 & 4.738 & 5.169 & 3.594 & - & - \\
\hline India & - & 0.956 & 28.223 & 4.642 & 15.138 & - & - \\
\hline
\end{tabular}


Table.6 Observed and forecasted production (in Metric tonnes) of arecanut in India

\begin{tabular}{|c|c|c|c|c|c|c|c|c|c|c|c|c|}
\hline \multirow[t]{2}{*}{ State } & \multirow[t]{2}{*}{ Model } & \multicolumn{3}{|c|}{ Observed } & \multicolumn{3}{|c|}{ Predicted } & \multicolumn{5}{|c|}{ Forecasted } \\
\hline & & 2013 & 2014 & 2015 & 2013 & 2014 & 2015 & 2016 & 2017 & 2018 & 2019 & 2020 \\
\hline \multirow[t]{3}{*}{ Assam } & $\operatorname{ARIMA}(4,2,0)$ & \multirow[t]{3}{*}{74.040} & \multirow[t]{3}{*}{74.040} & \multirow[t]{3}{*}{74.040} & 77.809 & 77.570 & 78.214 & 78.488 & 79.181 & 80.907 & 83.069 & 86.161 \\
\hline & $\operatorname{ARIMAx}(0,1,1)$ & & & & 74.521 & 76.600 & 78.683 & 76.641 & 78.572 & 80.644 & 82.852 & 85.221 \\
\hline & Combined & & & & 76.165 & 77.085 & 78.449 & 77.565 & 78.877 & 80.776 & 82.961 & 85.691 \\
\hline \multirow[t]{3}{*}{ Karnataka } & $\operatorname{ARIMA}(1,1,1)$ & \multirow[t]{3}{*}{348.770} & \multirow[t]{3}{*}{457.560} & \multirow[t]{3}{*}{460.000} & 356.077 & 354.771 & 459.645 & 463.756 & 466.248 & 469.814 & 472.535 & 475.988 \\
\hline & $\operatorname{ARIMAx}(2,2,0)$ & & & & 529.500 & 518.070 & 688.640 & 479.830 & 574.551 & 589.921 & 618.772 & 692.790 \\
\hline & Combined & & & & 442.789 & 436.421 & 574.143 & 471.793 & 520.400 & 529.868 & 545.654 & 584.389 \\
\hline \multirow[t]{3}{*}{ Kerala } & $\operatorname{ARIMA}(1,1,1)$ & \multirow[t]{3}{*}{113.360} & \multirow[t]{3}{*}{125.930} & \multirow[t]{3}{*}{128.000} & 97.767 & 112.908 & 125.401 & 128.146 & 128.518 & 128.921 & 129.330 & 129.740 \\
\hline & $\operatorname{ARIMAx}(0,1,1)$ & & & & 105.490 & 100.291 & 100.800 & 125.330 & 123.941 & 122.110 & 119.921 & 117.341 \\
\hline & Combined & & & & 101.629 & 106.600 & 113.101 & 126.738 & 126.230 & 125.516 & 124.626 & 123.541 \\
\hline \multirow[t]{3}{*}{ India } & $\operatorname{ARIMA}(0,1,2)$ & \multirow[t]{3}{*}{622.270} & \multirow[t]{3}{*}{746.660} & \multirow[t]{3}{*}{684.470} & 689.461 & 654.315 & 679.878 & 721.880 & 723.834 & 723.834 & 723.834 & 723.834 \\
\hline & $\operatorname{ARIMAx}(1,1,0)$ & & & & 679.640 & 659.291 & 713.842 & 780.911 & 812.863 & 875.510 & 922.031 & 975.452 \\
\hline & Combined & & & & 684.551 & 656.803 & 696.860 & 751.396 & 768.349 & 799.672 & 822.933 & 849.643 \\
\hline
\end{tabular}

Table.7 ARIMA, ARIMAx and Combined model for yield of arecanut in India

\begin{tabular}{|c|c|c|c|c|c|c|c|}
\hline \multirow[t]{2}{*}{ State } & \multirow[t]{2}{*}{ Models } & \multicolumn{4}{|c|}{ Model selection criteria } & \multicolumn{2}{|c|}{$\begin{array}{l}\text { Ljung-Box test for } \\
\text { residuals }\end{array}$} \\
\hline & & $\mathbf{R}^{2}$ & RMSE & MAPE & MAE & $\chi^{2}$ & P Value \\
\hline \multicolumn{8}{|c|}{ ARIMA Models } \\
\hline Assam & $(2,1,0)$ & 0.540 & 97.899 & 7.054 & 66.983 & 13.531 & 0.634 \\
\hline Karnataka & $(1,1,0)$ & 0.312 & 120.632 & 5.721 & 75.751 & 8.981 & 0.702 \\
\hline Kerala & $(1,1,2)$ & 0.921 & 63.344 & 4.632 & 43.552 & 3.201 & 0.991 \\
\hline India & $(0,1,1)$ & 0.783 & 69.051 & 4.203 & 45.981 & 13.573 & 0.331 \\
\hline \multicolumn{8}{|c|}{ ARIMAx Models } \\
\hline Assam & $(0,1,1)$ & 0.518 & 100.279 & 6.545 & 62.152 & 19.908 & 0.279 \\
\hline Karnataka & $(1,1,0)$ & 0.492 & 141.566 & 6.237 & 86.122 & 13.871 & 0.676 \\
\hline Kerala & $(0,1,1)$ & 0.899 & 73.555 & 5.145 & 50.410 & 6.245 & 0.991 \\
\hline India & $(0,1,1)$ & 0.802 & 81.421 & 4.778 & 54.601 & 23.939 & 0.121 \\
\hline \multicolumn{8}{|c|}{ ARIMA+ARIMAx } \\
\hline Assam & - & 0.554 & 95.783 & 6.747 & 63.860 & - & - \\
\hline Karnataka & - & 0.321 & 110.480 & 5.374 & 70.465 & - & - \\
\hline Kerala & - & 0.919 & 61.086 & 4.710 & 44.069 & - & - \\
\hline India & - & 0.769 & 70.353 & 4.412 & 48.478 & - & - \\
\hline
\end{tabular}


Table.8 Observed and forecasted yield (in $\mathrm{kg} / \mathrm{ha}$ ) of arecanut in India

\begin{tabular}{|c|c|c|c|c|c|c|c|c|c|c|c|c|}
\hline \multirow[t]{2}{*}{ State } & \multirow[t]{2}{*}{ Model } & \multicolumn{3}{|c|}{ Observed } & \multicolumn{3}{|c|}{ Predicted } & \multicolumn{5}{|c|}{ Forecasted } \\
\hline & & 2013 & 2014 & 2015 & 2013 & 2014 & 2015 & 2016 & 2017 & 2018 & 2019 & 2020 \\
\hline \multirow[t]{3}{*}{ Assam } & $\operatorname{ARIMA}(2,1,0)$ & \multirow[t]{3}{*}{966.960} & \multirow[t]{3}{*}{966.960} & \multirow[t]{3}{*}{937.220} & 934.352 & 977.226 & 966.960 & 946.077 & 953.938 & 948.470 & 947.324 & 949.596 \\
\hline & $\operatorname{ARIMAx}(0,1,1)$ & & & & 985.650 & 1001.850 & 1017.770 & 963.840 & 968.860 & 973.200 & 976.281 & 978.990 \\
\hline & Combined & & & & 960.001 & 989.538 & 992.365 & 954.959 & 961.399 & 960.835 & 961.803 & 964.293 \\
\hline \multirow[t]{3}{*}{ Karnataka } & $\operatorname{ARIMA}(1,1,0)$ & \multirow[t]{3}{*}{1587.560} & \multirow[t]{3}{*}{2098.800} & \multirow[t]{3}{*}{2090.910} & 1628.169 & 1637.503 & 1646.490 & 2115.755 & 2131.917 & 2150.382 & 2168.236 & 2186.252 \\
\hline & $\operatorname{ARIMAx}(1,1,0)$ & & & & 1548.311 & 1428.880 & 1484.461 & 1925.272 & 1824.291 & 1743.920 & 1688.681 & 1644.511 \\
\hline & Combined & & & & 1588.240 & 1533.192 & 1565.476 & 2020.514 & 1978.104 & 1947.151 & 1928.459 & 1915.382 \\
\hline \multirow[t]{3}{*}{ Kerala } & ARIMA(1,1,2) & \multirow[t]{3}{*}{1172.950} & \multirow[t]{3}{*}{1302.410} & \multirow[t]{3}{*}{1292.930} & 1019.838 & 1089.890 & 1053.559 & 1331.207 & 1299.281 & 1347.872 & 1333.737 & 1368.467 \\
\hline & $\operatorname{ARIMAx}(0,1,1)$ & & & & 1023.160 & 944.741 & 884.070 & 1265.711 & 1241.593 & 1217.811 & 1194.074 & 1170.460 \\
\hline & Combined & & & & 1021.499 & 1017.316 & 968.815 & 1298.459 & 1270.437 & 1282.842 & 1263.906 & 1269.464 \\
\hline \multirow[t]{3}{*}{ India } & $\operatorname{ARIMA}(0,1,1)$ & \multirow[t]{3}{*}{1377.010} & \multirow[t]{3}{*}{1658.470} & \multirow[t]{3}{*}{1504.330} & 1386.859 & 1397.541 & 1408.222 & 1543.605 & 1556.695 & 1569.786 & 1582.876 & 1595.966 \\
\hline & $\operatorname{ARIMAx}(0,1,1)$ & & & & 1401.750 & 1416.250 & 1586.070 & 1543.440 & 1550.160 & 1558.070 & 1566.890 & 1576.010 \\
\hline & Combined & & & & 1394.305 & 1406.896 & 1497.146 & 1543.523 & 1553.428 & 1563.928 & 1574.883 & 1585.988 \\
\hline
\end{tabular}

Leptokurtic and positive skewness clearly indicate that production of areca nut showed maximum shift or improvement at early stages. Among the states considered maximum compound growth rate found in Karnataka followed by Kerala and Assam. Karnataka even with highest average production followed by Kerala and Assam. In similarity with area and production Karnataka has recorded the highest average productivity followed by Assam while Kerala with lowest productivity. Kerala recorded highest CGR and SGR whereas negative growth is seen in case of Assam. Among the states considered, Assam and Karnataka are positively skewed whereas Kerala shows negative skewness. No outlier was detected for the series of areca nut and all series found to have trend except for yield of India. Also found that series of areca nut followed polynomial trend. Thus, it is evident from the study of these three crops, that Kerala is shifting its area from cashew nut in favour of coconut and areca nut.

Modeling and forecasting for area, production and productivity of areca nut indicates that compared to year 2015 area under areca nut in case of Assam, Kerala and whole India would increase in future whereas area in Karnataka would decrease. Thus, proper measures should be taken to arrest the decrease in area under areca nut in future.

Compared to the production of areca nut in 2015, the forecasted figures from ARIMA and ARIMAx models indicate that production of areca nut in Assam, Karnataka, Kerala and India as a whole would increase in future except for production of areca nut in Kerala which decreases slightly as predicted from its ARIMAx model.

The forecasted figures of yield of areca nut using ARIMA models compared with its yield in 2015 indicate possible increase of its yield in future while yield of areca nut in Karnataka and Kerala would decline as predicted by ARIMAx models, may be due to gestation period for new plantations.

\section{Acknowledgement}

The authors acknowledge and thank Department of Science and Technology for awarding Inspire fellowship for pursuing Doctoral Programme. 


\section{References}

Aman. 1969. Medicinal secrets of your food. 1st edition. Mysore: The Wesley Press; 1969, 700-2.

Anonymous. (Various issue). "Fertilizer statistics", Govt. of India.

Anonymous. 2018. Directorate of Economics and Statistics (DES). Department of Agriculture, Cooperation and Farmers Welfare, Ministry of Agriculture and
Farmers Welfare. GOI.

Box, G.E.P. and Jenkins, G.M. 1976. Time Series Analysis: Forecasting and Control, Holden-Day, San Francisco.

Dhekale, B. S, et al., 2014. Modeling and forecasting of tea production in West Bengal. J Crop Weed. 10, 94-103.

Hui, Z. and Yuhong, Y. 2004. Combining time series models for forecasting. International Journal of Forecasting. 20, 69-84

\section{How to cite this article:}

Lakshmi Narsimhaiah, P.K. Sahu, Sh Herojit Singh, Kanchan Sinha, Soumik Dey and Pramit Pandit. 2019. Modeling and Forecasting of Arecanut Production in India-Vision 2020. Int.J.Curr.Microbiol.App.Sci. 8(11): 728-738. doi: https://doi.org/10.20546/ijcmas.2019.811.087 